\title{
SOLOVJOV O POMENU PROTESTANTIZMA
}

\section{Peter Kovačič Peršin}

Vladimirja Sergejeviča Solovjova (1853-1900) štejejo za enega ključnih utemeljiteljev ruske filozofije. Značilnost njegove filozofije je, da izhaja iz osebnega izkustva in posega tako na teološko kot tudi na družboslovno področje. $\mathrm{V}$ tem pogledu je predhodnik personalizma kot posebne filozofske smeri, ki jo je v ruskem intelektualnem prostoru razvil nadaljevalec njegove filozofije Nikolaj Berdjajev. Ta pa je močno vplival na francoskega personalista Emmanuela Monierja in po njem na Edvarda Kocbeka.

Solovjov se je rodil v Moskvi v aristokratski družini izobražencev. Oče ji bil profesor na moskovski univerzi, njegov ded po očetu pa pravoslavni duhovnik, ki je Vladimirja še kot otroka v cerkvi posvetil za duhovno življenje. Mati je imela judovske korenine in je bila v sorodstvu z Romanovimi. Tako je bil vzgojen $v$ intelektualnem in poduhovljeno vernem okolju, a tolerantnem do različnih religioznih praks. V najstniških letih je izgubil vero. Navzel se je modne nihilistične in materialistične ideologije. Že v mladosti je ob študiju zgodovine in naravoslovja prebral temeljna dela zahodne filozofije. Iz filozofije je diplomiral s tezo Kriza zahodne filozofije. Proti pozitivizmu. Ta usmeritev je določila glavno smer njegove filozofije. Filozofske razglede je nato izpopolnjeval v Londonu, kjer se je posvetil tudi študiju mistike in gnostične misli. Tu je doživel svoje spreobrnjenje. Nato je odšel v Egipt, kjer je doživel mistično srečanje s Sofijo, Božjo modrostjo. Po vrnitvi v Rusijo leta 1878 je v Peterburgu imel znamenita predavanja o Bogočloveštvu (Čtenija o bogočelovečestve), ki veljajo za njegovo najpomembnejše delo. Po doktoratu s tezo Kriza abstraktnih načel je predaval na univerzi, dokler mu carska oblast ni prepovedala, ker je nasprotoval usmrtitvi atentatorjev na 
carja Aleksandra II. Nato se je osredotočil na študij duhovnih vprašanj in napisal znamenite spise: Duhovne osnove življenja (Duhovnija osnovi žizni), Smisel ljubezni (Smysl Ljubvi), Opravičenje dobrega (Opravdanije dobra), Trije dialogi in pripoved o Antikristu (Tri razgovora). Pisal je tudi o vprašanjih estetike in o lirični poeziji.

Poudariti velja, da ga je intelektualni, duhovni in družbeno angažirani razvoj privedel do ideje ekumenizma, ki je postala ena njegovih osrednjih preokupacij. Je prvi veliki ekumenist v ruskem pravoslavju, kar ga je osamilo v pravoslavnem okolju. Za razliko od takratnega katoliškega ekumenizma je zavračal idejo prozelitizma in zagovarjal enotnost krščanskih cerkva ob njihovi avtonomnosti in različnosti. Solovjov je edinost kristjanov pojmoval v duhovnem smislu kot edinost v Kristusu, kar vključuje različne konfesionalne prakse. Za katoliško teologijo je postal zanimiv zaradi naklonjenega odnosa do instituta papeštva. Vendar je nanj iz praktičnih razlogov gledal kot na moralno avtoriteto in simbol enotnega krščanstva, ne pa kot na vrhovno oblast enotne Cerkve. Ti nazori so ga zbližali z đakovskim škofom Josipom Jurajem Strossmayerjem, ki je bil velik pobudnik ekumenskega gibanja na Hrvaškem. Solovjovu je v Zagrebu izdal spis Zgodovina in prihodnost teokracije (Istorija i buduščnost teokratii). Na 1. vatikanskem koncilu (1870) je Strossmayer prav iz ekumenskih razlogov nasprotoval razglasitvi dogme o papeški nezmotljivosti. Temu je iz istih razlogov nasprotoval tudi koprsko-tržaški škof, Slovenec, Jernej Legat.

Solovjov je o pomenu protestantizma govoril v svojem drugem predavanju o Bogočloveštvu. $\mathrm{V}$ teh predavanjih, ki jih je imel v peterburškem Muzeju uporabnih znanosti od januarja 1878 do marca 1881, je govoril o sekularizmu kot civilizacijskem pojavu in njegovih posledicah. Izhajal je iz kritike evropske filozofije pozitivizma in racionalizma ter iskal odgovor na njeno nezadostnost. Pojav sekularizacije, ki je povzročala globoke duhovne spremembe v Evropi in tudi v Rusiji, je označil 
za temeljno značilnost novoveške civilizacije in ga prepoznal kot enega ključnih pojavov, ki bodo določali nadaljnji zgodovinski potek:

Težnja po organizaciji človeštva zunaj brezpogojne religiozne sfere, težnja po tem, da bi se utrdili in uveljavili na področju časnih, minljivih interesov, je značilna za sodobno civilizacijo. Najdosledneje, najbolj zavestno in popolno se ta težnja izraža v dveh sodobnih tvorbah: prva - socializem - je vezana predvsem na praktične interese družbenega življenja, druga - pozitivizem - pa stavi na teoretično plat znanstvene vednosti. Socializem in pozitivizem religije neposredno ne zavračata niti ne sprejemata, želita le zavzeti prazno mesto, ki ga je religija pustila v življenju in vednosti sodobnega omikanega človeštva. In prav s tega vidika ju moramo presojati. (Solovjov 2019,13)

Njegova kritika ključnih pojavov sekularizma ni ideološka. Ne zavrača našteta pojava, pač pa skuša razumeti vzroke za njuno uveljavitev in analizira njuno nepopolnost. V tem se bistveno razlikuje od sočasnih in tudi še današnjih ideoloških konfrontacij in njihovih politik, ki so in še povzročajo radikalne konflikte ter borbo med ideologijami, ki obvladujejo domala vse svetovne družbe. Na to dejstvo velja opozoriti, ker nam pojasnjuje tudi naš stoletni razkol in poskus njegovega preseganja, ki ga je na Slovenskem skušala uveljaviti filozofija personalizma (in politika krščanskega socializma), ki je razumela zgodovinsko nujo uveljavitve socializma. To njeno stališče izvira iz filozofije Solovjova.

Solovjovov pogled na protestantizem lahko v celoti razumemo, če osvetlimo imenovana pojava sekularizma. O zgodovinskem pojavu socializma razmišlja takole $(2019,13-14)$ :

Socializem je zgodovinsko upravičen predvsem kot neizogibna posledica, kot zadnja beseda zahodnega zgodovinskega razvoja. Francoska revolucija, ki je jasno določila temeljni značaj zahodne civilizacije kot zunaj religiozne civilizacije oziroma kot poskus, da bi zgradili stavbo vesoljne kulture in organizirali človeštvo na zgolj posvetnih, zunanjih nače-

1 Vsi navedki so vzeti iz: Vladimir Solovjov, Izbrani filozofski spisi (Ljubljana: KUD Logos, 2019). 
lih, francoska revolucija je, pravim, kot temelj družabne ureditve namesto prejšnje Božje postave razglasila človekove pravice. Človekove pravice lahko omejimo na dve osrednji: na svobodo in enakost, ki se morata zediniti/spraviti v bratstvu. Velika revolucija je razglasila svobodo, enakost in bratstvo. Razglasila, ne pa uresničila. Te tri besede so ostale prazne. Socializem je poskus dejanskega uresničenja teh treh načel. Revolucija je uvedla državljansko svobodo. Toda zaradi dejanske družbene neenakosti osvoboditev od enega gospodujočega razreda pomeni podreditev drugemu. Oblast monarhije in fevdalcev se je umaknila oblasti kapitala in buržoazije. Sama svoboda narodni večini ne daje nič, če ni enakosti. Revolucija pa je razglasila tudi enakost. Toda na našem svetu, ki temelji na boju, na neomejenem tekmovanju med posamezniki, ni enakost pravic nič brez enakosti moči. Načelo enakosti, enakopravnosti dejansko velja le za tiste, ki imajo v konkretnem zgodovinskem trenutku tudi moč. Toda zgodovinska moč prehaja iz enih rok v druge. In kakor je sedanji vodilni razred, buržoazija, načelo enakosti izkoristil v svoj prid, ker je imel v danem zgodovinskem trenutku moč, si siromašni razred, proletariat, seveda prizadeva, da bi načelo enakosti izkoristil v svoj prid, takoj ko bo moč v njegovih rokah.

Družbena ureditev mora imeti pozitivni temelj. Ta temelj ima bodisi nadnaravni in nadčloveški značaj bodisi je del pogojne sfere dane človeške narave; družba se opira ali na Božjo voljo ali na voljo ljudstva, na narodno voljo. Te dileme ne moremo izpodbijati s trditvijo, da družbeno ureditev lahko določa moč državne oblasti oziroma vlade, kajti tudi ta se na nekaj opira: ali na Božjo voljo ali pa na voljo ljudstva. Prvi člen tega vprašanja je zavrgla zahodna civilizacija; francoska revolucija je odločno odklonila tradicionalna načela in odločno postavila demokratično načelo, po katerem družbena ureditev temelji na volji ljudstva.

Ko Solovjov analizira družbene razmere porajajočega se kapitalizma, pride do razvidnosti dejanskega stanja zahodne demokracije, ki traja še danes: "Narod je sam svoj vladar samo de iure, de facto pa ima vrhovno oblast njegov neznatni del - bogata buržoazija, kapitalisti.« (Solovjov 2019,15) Kapital je danes temelj družbene moči. »Svoboda in enakopravnost sta za večino le abstraktni možnosti.« (str. 15) Zato pride do utemeljenega sklepa: »Potemtakem je prizadevanje socializma za enakost, kar 
zadeva gmotno blaginjo, torej prizadevanje, da bi gmotna blaginja prešla iz rok manjšine $\mathrm{v}$ roke narodne večine popolnoma naravno in zakonito, še zlasti $z$ vidika načel, ki jih je razglasila francoska revolucija in ki so temelj vse sodobne civilizacije. Socializem je v tem smislu zgodovinsko upravičen in bo na Zahodu v bližnji prihodnosti prišel na svoj račun. Toda socializem noče biti le zgodovinska sila in imeti le pogojno upravičenost - socializem hoče biti višja nravstvena moč, prisvaja si pravico do udejanjanja brezpogojne pravičnosti (правда) v družbeni ureditvi. In prav tu neizogibno in usodno prihaja v protislovje sam s seboj in njegova zgrešenost postaja očitna.« (str. 15-16) Namreč, težnja po gmotni blaginji je za vsakega nekaj naravnega in nujnega, prav tako potreba po pravični razdelitvi dobrin, ugotavlja Solovjov in sklepa (str. 17):

Socializem ima vsekakor prav, da se upira sedanji socialni krivičnosti. Toda od kod izvira ta krivičnost? Nedvomno od tod, da družbena ureditev temelji na sebičnosti posameznikov, od koder izvirajo njihova tekmovalnost, boj, sovraštvo in vse družbeno zlo. Če pa je izvir socialne krivičnosti v sebičnosti, mora biti socialna pravičnost zasnovana na nečem, kar temu nasprotuje, se pravi na načelu samoodpovedi ali ljubezni.

Ta točna, a zgoščena analiza razkriva bistvoglednost Solovjovega mišljenja. Čeprav v socializmu vidi pozitiven družbeni razvoj glede na socialno in gospodarsko preureditev družbe, pa tudi jasno opozori na bistveno nemožnost za njegov uspeh, na njegovo notranje protislovje. In dejansko se je kot totalitaren revolucionarni projekt zgodovinsko uveljavljal z nasiljem. Kot tak je izkazoval vse značilnosti religije, kar Solovjov vidi v njegovi volji, da se »udejanji kot brezpogojna resnica«. Brezpogojna resnica je možna samo v območju religiozne totalitete, njen temelj je vera, ki pa v sekularni družbi in ob njenih nazorih ne more biti kriterij preverjanja ustreznosti delovanja družbe. Socializem kot sekularno gibanje za družbeno preobrazbo kot tak nima moralnih vzvodov, da bi ideal pravične družbe tudi udejanjil. Pravičnost ni kategorija družbenega reda, pač pa duhovno-moralne drže posameznika.

Danes je jasno, da vsaka družbena teorija in praksa, ki sta utemeljeni na kvazireligiozni totaliteti in ne na duhovno-moralni drži, vodita $\mathrm{v}$ 
družbeno nasilje, ki ga totaliteta terja, da bi uresničila zadani projekt. Zato tudi nujno doživita propad na ruševinah družbenega sistema, ki ga skušata zgraditi, in na truplih svojih žrtev. Religiozna totaliteta išče svoje absolutno poroštvo $\mathrm{v}$ eshatologiji dokončne dopolnitve v območju metafizike, ki ni svet racionalnega izkustva, ampak predmet vere. In če religiozna institucija svoj cilj eshatološke uresničitve postavlja v svet materialne zgodovinskosti, zapade v enako totalitarno nasilje do človeka kot druge totalitarne ideologije. Vera je duhovna kategorija, ki je drža osebe. Če torej hoče verska skupnost, ki je to le, dokler ostaja občestvo v duhu združenih članov, graditi Božje kraljestvo na zemlji, se pravi v zgodovini, $\mathrm{z}$ metodami svetne družbe, torej s politično in $\mathrm{z}$ gospodarsko močjo, postane institucija nasilja nad človekom in doživlja svoj propad kot občestvo vernikov.

Solovjov naglaša, da si socializem religiozno veljavo skuša prisvojiti s tem, ker hoče zasledovati cilje krščanske morale z nekrščanskimi metodami: »Socializem včasih kaže namero po udejanjanju krščanske morale. V zvezi s tem je nekdo duhovito pripomnil, da je med krščanstvom in socializmom v tem oziru samo ta mala razlika, da krščanstvo zahteva, da razdamo svoje, socializem pa zahteva, da vzamemo tuje [...].« (str. 17) Dejansko pa kot materialističen nazor nima notranjega naboja za nesebično delo, ampak se uveljavlja kot volja do moči, kot absolutna oblast. S tem pa zgreši oziroma zapravi svoj zgodovinski cilj. Etična drža namreč v človeku ni utemeljena materialistično, ampak duhovno.

Ideja socializma kot boja za družbo solidarnosti med ljudmi, njihove enakosti in svobode ne more biti utemeljena na etičnem relativizmu, ki opravičuje nasilje nad človekom in privilegira le svoje privržence. Kot revolucionarna praksa pa pozna in prizna le lastne interese. Svoj cilj hoče doseči takoj, zato brez nasilja ne more uveljaviti brezrazredne družbe, ki je po naravi svoje totalitete kvazireligiozen projekt. Prav na to dejstvo opozarja Solovjov. Danes je jasno, da je socializem kot družbeni projekt mogoč samo kot utopična vizija, ki jo je možno izgrajevati le kot permanentno družbeno reformo, ki pa mora temeljiti na etiki odgovornosti vsakega posameznika. Etika brezpogojne odgovornosti pa pri konkretnem človeku ne deluje, če ni metafizično utemeljena, če je ta 
zavezan samo pragmatičnim interesom, ki so utemeljeni na sebičnosti. V tem smislu Solovjov poudarja, da mora imeti socializem, če hoče uresničiti svojo vizijo pravične družbene ureditve, religiozno utemeljitev. Iz tega njegovega stališča izhaja teorija krščanskega socializma. Kot družbeno teorijo ga je pri nas domislil Andrej Gosar, kot prakso pa so ga skušali udejanjiti krščanski socialisti, tudi s teoretičnim premislekom o revolucionarni etiki predvsem Edvard Kocbek. Zgodovinska usoda njihovega projekta, ki je lahko zaživela le v sodelovanju s komunističnim revolucionarnim projektom, pa je znana.

Te dileme je Solovjov dogledal že desetletja pred oktobrsko revolucijo (str. 19-20):

Socializem s svojo zahtevo po družbeni resnici in z nezmožnostjo, da bi to resnico udejanjil na končnem naravnem temelju, logično vodi do priznanja nujnosti religije. [...] Socializmu ne moremo odreči legitimne želje po realizaciji nravstvenega načela, po tem, da bi ta načela vpeljal na mejna področja življenja, v materialne in ekonomske odnose. A za to, da bi človek lahko udejanjil resnico v nižjih sferah življenja, mora ta resnica najprej obstajati sama, neodvisno od človeka, tako kot mora imeti resnica najprej svojo lastno resničnost in šele nato lahko postane dejstvo za človeka. [...] Toda ta brezpogojna resničnost je sama po sebi dostopna le neposrednemu dojemanju, notranjemu razodetju, kar pomeni, da je predmet religiozne vednosti. Toda socializem kot pozitivizem, če dosledno razvijamo njuna načela, vodita k zahtevi po religioznem načelu v življenju in vednosti.

Solovjov to govori s stališča deideologizirane religije. Iz žive vere osebnega izkustva, ki je duhovne narave. Zato je tudi do zgodovinskega udejanjanja krščanstva kritičen. Iz spoznanja in izkušnje osebne vere pride do sklepa, da sta utopičen projekt družbe socialne pravičnosti in življenje iz osebne vere možna le na platformi udejanjene vere "Bogočloveštva«, kakor on poimenuje izvorno krščansko vero. Na ravni te duhovne strukture se socializem kaže kot možnost in perspektiva, toda v stvarnosti zgodovinskega dogajanja ostaja le utopija, ki je lahko vzpodbuda in gibalo nenehne družbene reforme. Kot totalen zgodovinski projekt je utopija. Do tega spoznanja pa so izkustveno prišli šele 
krščanski socialisti, ki so se revolucije udeležili. Usoda Berdjajeva, ki se je udeležil oktobrske revolucije, je podobna usodi Edvarda Kocbeka. Oba sta izkusila bestialnost revolucije in utopičnost njene ideologije, ker ni bila utemeljena na duhovno-moralni drži človeka. Le na tej osnovi osebne vere in moralne odgovornosti bi bil socializem kot zgodovinski projekt možen. A zaradi prepričanja, da je mogoča simbioza socializma in izvornega krščanstva, je Kocbek kljub izkušnji revolucionarnega zla ohranil upanje, da je socialna preobrazba družbe - socializem - mogoča na temelju krščanskega etosa. Iz enakega upanja je zraslo tudi gibanje teologije osvoboditve v Latinski Ameriki. Navdih je tej smeri krščanskega socializma dal Solovjov s svojim prepričanjem v to simbiozo, ki ga je formuliral v izjavi (str. 34):

Stara tradicionalna religija izhaja iz vere $\mathrm{v}$ Boga, a te vere ne izpelje do konca. Sedanja zunajreligiozna civilizacija izhaja iz vere v človeka, a je prav tako nedosledna - svoje vere ne izpelje do konca. Če ti dve veri - vero v Boga in vero v človeka - dosledno izpeljemo in do konca udejanjimo, se stakneta v edini popolni in celostni resnici Bogočloveštva. ${ }^{2}$

Na osnovi te analize Solovjov odpira bistven vidik svojega pogleda na religijo in s tem na sekularizem kot umanjkanje religiozne zavesti in drže sodobnega človeka (str. 20): »Religija je zedinjenje človeka in sveta $\mathrm{z}$ brezpogojnim in celostnim Prapočelom. To Počelo kot celostno in vseobsegajoče ničesar ne izključuje, zato tudi resnično zedinjenje z njim, resnična religija ne more izključevati ali zatirati ali si nasilno podrejati prav nobene prvine, nobene žive moči v človeku in njegovem svetu.«

2 Edvard Kocbek je to idejo izrazil s teološko govorico nauka o inkarnaciji (nauka o učlovečenju Boga): „Osrednji krščanski dogodek je inkarnacija [...]. Osrednji krščanski dogodek se torej sam iz sebe upira sleherni dematerializaciji in begu v nedejavnost [...]. Kdor je resnično religiozen, bo $\mathrm{z}$ neustavljivo silo težil $\mathrm{v}$ inkarnacijo svoje vere. Hotel bo utelesiti vero v vsem svojem življenju [...].«. Edvard Kocbek, Tovarišija (Maribor: Obzorja, 1967), 69. 
Solovjov jasno razmeji med religijo kot osebno vero od pripadnosti konfesionalni ideologiji in instituciji. Le »s tega stališča se religiozno načelo kaže kot edino dejansko uresničenje svobode, enakosti in bratstva« (str. 21).

Rekel sem, da mora biti o smislu religiozne ideje zedinjenje posameznih bitij ter zasebnih načel in moči z brezpogojnim Počelom svobodno; to se pravi, da morajo posamezna bitja in zasebna načela sama od sebe ali po svoji volji priti k zedinjenju ali brezpogojnemu soglasju, sama se morajo odpovedati svoji izključujočosti, samouveljavljanju ali sebičnosti. Pot k odrešitvi, k uresničenju resnične enakosti, svobode in bratstva vodi skozi samozanikanje. A samozanikanje zahteva najprej samouveljavitev: da se svoji izključujoči volji lahko zares odpovem, jo moram najprej imeti; da se zasebna načela in moč svobodno zedinijo z brezpogojnim Počelom, se morajo od njega najprej ločiti, vztrajati pri svojem, si prizadevati za izključujoče gospostvo in brezpogojno veljavo. Kajti le resnično izkustvo, le to, da doživimo protislovje, da izkusimo izvorno zgrešenost samouveljavljanja, lahko vodi k prostovoljni odpovedi njemu samemu ter k zavestni in svobodni zahtevi po zedinjenju z brezpogojnim Počelom. Od tod je razviden veliki smisel negativnega zahodnega razvoja, veliko poslanstvo zahodne civilizacije.

Potreben je torej obrat, ki se sprva izraža v prevladujočem pesimizmu, ki je zajel zahodnega človeka, ugotavlja Solovjov. Napoveduje, da bo korenit obrat v sistemu vrednot nastopil šele po polomu socialističnega projekta (str. 23):

Korenit obrat, velika kriza v zavesti zahodnega človeka se je že začela. Očiten dokaz tega sta razvoj in uspeh pesimizma. [...] Ta pesimizem, obrat k samozanikanju se za zdaj izraža le v teoriji, v filozofskem sistemu, ${ }^{3}$ a predvidevamo lahko, da bo kmalu, in sicer prav takrat, ko bo na Zahodu zmagala socialna revolucija in bo sama sprevidela jalovost svoje zmage, svojo lastno zgrešenost in nezmožnost, da bi zgradila harmonično in

3 Solovjov je to pisal konec 19. stol. pod vtisom filozofije Schopenhauerja in Hartmanna, a predvidel tudi sedanji čas, ko zahodnega človeka množično obvladuje nihilizem. 
pravično družbeno ureditev, da bi uveljavila pravičnost na podlagi minljive biti, ko se bo torej zahodno človeštvo iz svoje lastne izkušnje, iz same zgodovinske resničnosti prepričalo, da je samouveljavljanje volje, pa naj bo to kakršnokoli že, izvor zla in trpljenja, da bo torej takrat pesimizem kot obrat k samozanikanju prešel iz teorije v življenje in bo zahodno človeštvo pripravljeno sprejeti religiozno načelo, pozitivno razodetje resnične religije.

A po zakonu delitve zgodovinskega dela isti kulturni tip, isti narod ne more uresničiti dveh svetovnih idej, udejanjiti dveh zgodovinskih nalog. In če je bila naloga zahodne civilizacije, da s svojim svetovnim poslanstvom uresniči negativni prehod iz religiozne preteklosti v religiozno prihodnost, bo naloga, da začne religiozno prihodnost razvijati, pripadla drugi zgodovinski sili.

Ta vizija Solovjovu odpre uvid v dokončanje zahodne civilizacije v njenem zgodovinskem poslanstvu. Danes, ko najtreznejši kritični misleci Zahoda zaton naše civilizacije že opisujejo kot dejstvo, lahko pritrdimo njegovemu predvidevanju. Izhajajoč iz njegove filozofije pa se odpira vprašanje, kakšno možnost ima protestantizem pri oblikovanju nove religiozne prihodnosti. Krščanski socialni misli in akciji pa se zastavlja vprašanje, ali današnje krščanstvo zahodne civilizacije še premore duhovno moč za korenito reformo, ki bi dala idejno in duhovno podlago pravičnejši družbeni ureditvi. Še bistvenejše je vprašanje, ali lahko zahodno krščanstvo s svojimi teološkimi koncepti sploh zmore dati odgovor na osnovno in ključno vprašanje, kako pojmovati Boga kot stvarnika in odrešenika človeštva v obzorju nastajajoče nove, t. i. kozmične podobe sveta spričo dosedanje ontoteološke paradigme, ki še vedno prevladuje v teoloških učenjih. Dogmatične predstave ne morejo dati ustreznega odgovora porajajoči zavesti današnjega človeka. In, ali zahodno človeštvo še ima toliko vitalnosti, da bi podvig za novo civilizacijsko strukturo lahko vzniknil v našem okolju, ki je duhovno obubožano in etično razkrojeno. Pred korenitim obratom ni samo svetna družba, še pred večjim je krščanstvo, če se hoče inkorporirati v svet jutrišnje civilizacije kot njen duhovni temelj. Sicer bo to postala neka druga religiozno-duhovna platforma. 
Kje Solovjov vidi poskus modernega uresničenja religioznega načela? O tem vprašanju je spregovoril v zvezi s protestantizmom v drugem predavanju, in sicer o njegovem civilizacijskem prispevku k razvoju novoveške evropske zavesti. Protestantizem razume kot korak k novi civilizaciji. Če je "poslanstvo razvoja zahodne zunajreligiozne civilizacije to, da za človeštvo pomeni prehod iz religiozne preteklosti v religiozno prihodnost «, ima po njegovem mnenju tu vlogo reformirano krščanstvo. Namreč, religiozno preteklost Solovjov vidi v rimskem katolištvu, v njegovi »poglavitni neresnici«. Prepričan je, da ima katolištvo še vedno veljavo, dokler se ne bo udejanjil prehod k celovitejši obliki krščanske religije.

Preteklost lahko izniči, dejansko in dokončno odpravi le načelo, ki bo dalo več, kot nam daje preteklost sama, ne pa votlo in nemočno zanikanje. Prav zato katolištvo še vedno vztraja in se trmasto bojuje proti družbenemu in intelektualnemu napredku - napredku, ki bo staro načelo usodno in nezadržno premagal šele takrat, ko bo prišel do pozitivnih sklepov, ko bo ustvaril temelje, na katerih bo mogoče zgraditi nov svet, ki ne bo le svobodnejši, temveč tudi duhovno bogatejši. (Solovjov 2019, 23)

$\mathrm{V}$ čem Solovjov vidi poglavitno neresnico katoliškega krščanstva? "Splošna ideja katolištva je predvsem to, da morajo biti vse svetne oblasti in načela, vse moči družbe in posamičnega človeka podrejene religioznemu načelu, da si mora Božje kraljestvo, ki ga na zemlji uteleša duhovna skupnost, Cerkev, podrediti kraljestvo tega sveta.« (str. 24) Solovjov pritrjuje dejstvu, ki izvira iz samega religioznega načela, ki najgloblje in najceloviteje določa strukturo osebe, namreč dejstvu, da

če je Cerkev v resnici Božje kraljestvo na zemlji, se ji morajo vse druge moči in oblasti podrediti, postati morajo njeno orodje. [...] Kraljestvo sveta mora biti podrejeno Božjemu kraljestvu, svetne moči družbe in človeka morajo biti podrejene duhovni moči. A kako razumeti to podrejenost in kako, s kakšnimi sredstvi se mora ta podrejenost udejanjati? (str. 24-25) 
Narava in način te podreditve morata očitno ustrezati tistemu brezpogojno božanskemu počelu, v imenu katerega se ta podreditev tudi udejanja. In ker je v krščanstvu Bog prepoznan kot ljubezen, razum in svobodni duh, to obenem že izključuje vsakršno suženjstvo in prisilo, vsakršno temno in slepo vero: podreditev svetnih načel božanskemu Počelu mora biti svobodna in se mora udejanjati z notranjo močjo podrejajočega se načela. [...] Duhovna skupnost (Cerkev) si mora podrediti svetno družbo, in sicer tako, da jo povzdigne k sebi, da jo poduhovi, da svetni element spremeni v svoje orodje in sredstvo - v svoje telo. Zunanja edinost je sam po sebi naravni izid tega procesa. $V$ katolištvu pa zunanja edinost ni izid, ampak temelj in cilj obenem. A če je zunanja edinost cilj, je sredstvo lahko le eno zunanja sila; katolištvo si jo prisvoji in se tako postavi ob bok zunanjim, se pravi svetnim silam. [...] Katolištvo kot višje načelo - načelo splošnega zahteva, da se mu delno in posamično podredita, zahteva podreditev človekove osebnosti. [...] Njegovo dejansko gospostvo se kaže le še v nasilju in zatiranju, ki izziva nujen in upravičen protest osebnosti, $v$ čemer je bistvo in tudi upravičenost protestantizma. (str. 26)

Ima sodobni protestantizem, ki izhaja iz svobode avtonomnega človeka in hkrati ohranja religiozno strukturo občestva, to je žive Cerkve, to moč? Gotovo ima boljše izhodišče kot rimski katolicizem ali bizantinsko pravoslavje. Cerkveno strukturiran protestantizem je usvojil ekumensko zavest, da lahko nepristransko in odprto korespondira tako s katolištvom kot s pravoslavjem pa tudi z judovstvom, islamom in budizmom, in že v tem je njegova prednost. Predvsem pa ima prednost $\mathrm{v}$ duhovni osvoboditvi človeka. Če katolištvo zahteva, da se mu podredi človekova osebnost - in s tem izziva nujen in upravičen protest osebnosti -, je protestantizem odpravil gospostvo nad človekovo osebnostjo, dal je človeku zavest avtonomne osebe tudi v odnosu do Boga. V tem je njegova novost in civilizacijska prednost:

S protestantizmom se $\mathrm{v}$ zahodni civilizaciji začenja postopno osvobajanje človekove osebe, osvobajanje človekovega jaza od zgodovinske vezi, utemeljene na tradiciji, ki je združevala, a obenem tudi zasužnjevala ljudi $\mathrm{v}$ srednjem veku. Veliki smisel procesa, ki se je začel z religiozno reforma- 
cijo, je v tem, da je osamil človekovo osebnost, jo prepustil sami sebi, da bi se lahko zavestno in svobodno usmerila k božanskemu Počelu, se z njim popolnoma zavestno in svobodno povezala.

Takšna vez ne bi bila mogoča, če bi bilo božansko Počelo za človeka nekaj čisto zunanjega, če ne bi bilo zakoreninjeno v sami človeški osebi; v takšnem primeru bi bil človek lahko božanskemu Počelu le suženjsko, usodno podrejen. Svobodna notranja vez med brezpogojnim božanskim Počelom in človeško osebo je mogoča le zato, ker ima sama človeška oseba brezpogojen pomen. Človeška oseba se lahko svobodno notranje zedini $\mathrm{z}$ božanskim Počelom le zato, ker je tudi sama v nekem smislu božanska, oziroma natančneje, ker je udeležena v Božanstvu. (str. 26-27)

A v čem je ta brezpogojnost, ta božanskost človeške osebe? Solovjov poudarja, da v možnosti. Zaveda se, da se

sodobni človek samega sebe zaveda kot notranje svobodnega, višjega od vsakršnega zunanjega, od sebe neodvisnega Počela, razglaša se za središče vsega, medtem ko je v resnici le neskončno majhna in izginjajoča točka na krožnici sveta. Sodobna zavest človeški osebi priznava božanske pravice, ne daje pa ji božanskih moči ne božanske vsebine: sodobni človek namreč tako v življenju kot v vednosti dopušča le omejeno pogojno stvarnost, stvarnost posamičnih dejstev in pojavov, in s tega vidika je tudi človek sam zgolj eno takšnih dejstev. [...] Zahodna civilizacija je osvobodila človekovo zavest vseh zunanjih omejitev, priznala je negativno brezpogojnost človeške osebe, razglasila brezpogojne človekove pravice. A s tem ko je zavrgla vsako brezpogojno Počelo v pozitivnem smislu, se pravi Počelo, ki dejansko in po svoji naravi razpolaga s celotno polnostjo biti, ko je človekovo življenje in zavest omejila na pogojno in prehodno, je hkrati utrdila tako neskončno težnjo kot tudi nezmožnost njene zadovoljitve. (str. 27-28)

Torej,

človekov jaz je brezpogojen $\mathrm{v}$ možnosti in ničev $\mathrm{v}$ resničnosti. $\mathrm{V}$ tem protislovju sta zlo in trpljenje, $\mathrm{v}$ njem je nesvoboda, človekova notranja zasužnjenost. Osvoboditev iz sužnosti je mogoča le v doseganju brezpogoj- 
ne vsebine, tiste polnosti biti, ki jo potrjuje neskončna težnja človekovega jaza. »Spoznajte resnico in resnica vas bo osvobodila.« (Jn 8,32)

Začetek resnice je prepričanje, da oseba ni samo negativno brezpogojna (kar je dejstvo), se pravi, da se noče in se niti ne more zadovoljiti z nobeno pogojno in omejeno vsebino, ampak da lahko doseže tudi pozitivno brezpogojnost, kar pomeni, da ima lahko celostno vsebino, polnost biti, in da potem ta brezpogojna vsebina, polnost biti, ni zgolj fantazija, subjektivni privid, ampak čisto prava resničnost, resničnost, polna moči. Vera vase, vera $v$ osebo je obenem tudi vera $v$ Boga, kajti božanskost pripada tako človeku kot Bogu, razlika je le ta, da Bogu pripada v večni resničnosti, človek pa jo lahko le dosega, usvaja, kar pomeni, da je v njegovem stanju božanskost zgolj možnost, zgolj težnja.

Preden lahko človek v življenju doseže to brezpogojno vsebino, jo mora doseči v zavesti; predno jo spozna kot resničnost zunaj sebe, jo mora uzavestiti kot idejo $v$ sebi. Pozitivno prepričanje o ideji je prepričanje o njenem obstoju, saj je neudejanljiva ideja le privid in prevara, in če je ne verovati v Boga brezumno, je še bolj brezumno verovati vanj napol.

Stara tradicionalna oblika religije izhaja iz vere v Boga, a te vere ne izpelje do konca. Sodobna zunajreligiozna civilizacija izhaja iz vere v človeka, a je prav tako nedosledna - svoje vere ne izpelje do konca. Če ti dve veri - vero v Boga in vero v človeka - dosledno izpeljemo in do konca udejanjimo, se strneta v edini popolni in celostni resnici Bogočloveštva. (Solovjov 2019, 33-34)

Toda ta vera je kot vera le prepričanje iz spoznanja. «Da Bog je, verjamemo, kaj je, pa izkušamo in vemo.» (str. 43) Izkusiti Boga pa je mogoče le v tistem, kar Bog - po krščanskem verovanju - je, v ljubezni, ki je celovita. Ljubezen do sočloveka je izraz ljubezni do Boga. Ljubiti Boga brez konkretne ljubezni do človeka, ni mogoče. »Brezpogojna ljubezen je prav tisto idealno vse, je celota, ki predstavlja vsebino božanskega Počela.« (str. 56) 
Pred to nalogo stojijo danes sodobni kristjan in krščanska občestva ne glede na to, kateri konfesionalni organizaciji (cerkvi) pripadajo. Solovjov je do teh spoznaj prišel na osnovi mistične vere, ki je lastna izvornemu, neinstitucionaliziranemu pravoslavju. Zato je lahko uvidel epohalni pomen in nalogo protestantske reformacije. In ta njegova dognanja kažejo protestantizmu tisto poslanstvo, ki naj bi ga izpolnil kot svojo civilizacijsko dolžnost.

Solovjov je na protestantizem gledal pozitivno s treh vidikov. Že to, da jemlje reformirane cerkve, po jedru njihove vere enake drugim cerkvam, pravoslavnim in rimokatoliškim, je za pravoslavno ekleziologijo izjemna ekumenska gesta. Predvsem pa daje protestantizmu dva bistvena pomena za civilizacijski razvoj t. i. krščanske civilizacije. S tem, da je dal človeku zavest avtonomnosti tudi v odnosu do Boga, je bistveno prispeval k sistemu vrednot moderne, kjer ima človek kot avtonomna osebnost središčni položaj. Kot tak je človek osebno zavezan moralni odgovornosti za svoje ravnanje. Od tod izvira pregovorna protestantska etika.

S svojo antropologijo je protestantizem začrtal smer sodobne civilizacije kot humane in s tem bistveno prispeval k inkulturaciji krščanstva v svet modernosti. Poseben pomen pa mu Solovjov pripisuje v obdobju civilizacije sekularizma. Upanje za to svojo tezo išče v civilizacijskem razvoju Evrope. In v tem se približa današnji izkušnji, da pozitivne premike lahko prinesejo le celostne reforme, ki spreminjajo tako zavest človeka kot tudi družbeni ustroj. Reformizem je pravzaprav eden temeljnih vzgibov razvoja zahodne civilizacije, ker spreminja človekovo osebno zavest in po njegovem delovanju družbo. Osebo, posamičnega človeka postavlja v središče življenja. Vsakršna družbena preobrazba izhaja iz osebno odgovornega moralnega delovanja človeka. Ne iz kolektiva. To je temeljni aksiom personalizma in krščanskega socializma. Solovjov ga je prepoznal že v jedru protestantske reformacije. V njem ni videl le religiozne reforme, ampak predvsem proces metafizičnega osvobajanja človeka, kar je bistveno vplivalo na novoveško umestitev človeka v svet 
in družbo. V tem ima protestantizem kot eno od gibanj pozne renesanse epohalen pomen.

Reformacija je prinesla celovito civilizacijsko preoblikovanje. V tem je njen epohalni pomen. Uveljavila je novo metafizično samorazumevanje človeka, kar je vplivalo tako na reformo religije kot tudi na nov družbeni sistem, na vzpostavitev kapitalizma in vzpon meščanske družbe, ki je odpravila fevdalno družbeno strukturo. Katolicizem še do danes vztraja pri fevdalni strukturiranosti svoje institucije. Vzpostavitev posameznika kot avtonomne osebe je korenito reformo povzročila tudi na teološkem področju. S tem ko je protestantizem odpravil hierarhično strukturo, je preoblikoval krščansko skupnost (cerkev) v enakopravno skupnost verujočih, kar jo je prizemljilo na mero demokratične družbene ureditve. To pa je dalo vzpodbudo za postopno demokratizacijo svetne družbe. Hkrati pa protestantska samopostavitev človeka kot osebe odpre možnost za odprt razvoj človekove zavesti, ki se odraža v permanentni modernizaciji življenja zahodne civilizacije. Pogoj za pozitiven razvoj v družbo modernosti pa vidi Solovjov v človeku, ki naj dozori v osebnost. V tej njegovi ideji se je porodil personalizem kot zgodovinsko gibanje in kot življenjska filozofija. »Človeška oseba - ne človeška oseba na splošno, v abstraktnem smislu, temveč konkretna živa oseba, vsak posamični človek - ima brezpogojen božanski pomen. V tej trditvi se krščanstvo stika s sodobno svetno civilizacijo.» (Solovjov 2019, 27) Protestantska reformacija krščanstva je dejanski začetek tega procesa.

Solovjov ta stik krščanstva $\mathrm{z}$ modernostjo odkriva v osebnem odnosu človeka do božanskega Prapočela. Glede na ta pojem osebe bi mogel današnji protestantizem vzpodbudo za tako korenit religiozno-civilizacijski obrat dobiti prav pri Sörenu Kierkegaardu, v njegovi filozofiji eksistence posamičnika, ki se kot taka vzpostavlja v odnosu do Boga preko odnosa do sočloveka. Personalisti pozneje posamičnika »definirajo « kot osebo. Filozofija osebe, ki jo v osnovi opredeli Solovjov v zgoraj navedeni ugotovitvi, ugotavlja nepopolnost ontološke definicije osebe, ker je v eksistenci človeka novoveške ozavestitve odkrival odprto strukturo, ki je ni mogoče zaobjeti s klasičnimi pojmi ontoteologije. Napravil je odmik od statične predstavnosti k bivanjski danosti, ki je dostopna le iz- 
kustveni percepciji. Ta miselni obrat je Solovjov odkril v protestantizmu kot celoviti koncepciji in udejanjenju posameznega človeka kot avtonomne osebe $\mathrm{z}$ osebnim etičnim temeljem in lastno samoutemeljitvijo. S tem duhovno-družbenim procesom se je začela eksistencialna avantura novoveškega človeka zahodne civilizacije, ki pa je, tako Solovjov, zaradi ateizacije, ko se moderni človek ne razume in ne vzpostavlja več v odnosu do božanskega Prapočela, pripeljala do pesimizma kot splošne klime sodobnega življenja. To stanje pa zahteva nov obrat tudi v krščanski teološki koncepciji. Protestantska teologija in eksegeza je z demitologizacijo, ki jo je začel Rudolf Bultman in so jo nadaljevali njegovi nasledniki, izrazito Karl Barth, ta obrat izvedla. Zato protestantska teologija zmore verodostojneje nagovoriti sodobnega človeka, kot ga katoliška ali pravoslavna, ki ostajata zapredeni v mitično podobo sveta.

Če hoče današnji protestantizem ostati zvest svojemu izvoru in če hoče dokončati "modernizacijo « krščanstva, se mora vrniti k protestu in h koreniti reformi. To pa bi se v obdobju obnavljanja totalitarizma neoliberalne agende moglo izvršiti v simbiozi s socializmom kot gibanjem in politično akcijo za vzpostavitev pravičnejše družbene ureditve in obnove/uveljavitve svoboščin in človekovih pravic, kar je bila izvorna težnja francoske revolucije kot rojstva sodobne civilizacije. S tem bi socializem dobil notranji etično-duhovni naboj v zavesti in drži posameznega človeka. Del tega je protestantizem že začel z uveljavljanjem družbenoodgovorne etike tudi v pogojih kapitalizma. Enako je v okviru katolicizma počel krščanski socializem. Edino v tej simbiozi duhovno-moralne preroditve $\mathrm{z}$ družbeno osvoboditvijo ima krščanstvo $\mathrm{v}$ sodobnem svetu sekularizacije perspektivo. 